\title{
Distribution of root carbon storage of Salix gordejevii at different forest
}

\author{
age \\ Wang Juan ${ }^{1 \mathrm{a}}$, Guo Yue Feng ${ }^{1 \mathrm{~b}}$, Yao Yun Feng ${ }^{1 \mathrm{c}_{*}}$, Tang Jun $^{1 \mathrm{~d}}$ \\ ${ }^{1}$ Department of Ecology and Environmental Science, Inner Mongolia Agricultural University, Hohhot \\ in Inner Mongolia, 010018, China \\ a wanghaijuan1109@126.com, b guoyuefeng0525@126.com, ${ }^{c}$ 18904718855@163.com, \\ d1275489130@qq.com
}

Keywords: S. gordejevii; root; carbon storage; distribution characteristics

Abstract: Comparative distribution characteristic of root system and the root system carbon stocks from three forest age of S. gordejevii in Aohan sanditificational. And three plots were set by using stratified segmentation mining method to test the root biomass and the carbon ratio in different soil assays and segment, and calculate root carbon reserves, analyzing distribution characteristics of forest root carbon stocks on different S. gordejevii in different forest ages. With the increase of soil depth, S. gordejevii root biomass presents the trend of increase first then decrease, mainly in soil of $0-100 \mathrm{~cm}$, which accounted for more than $80 \%$ of the total; with the increase of forest age, S. gordejevii root biomass presenting a growing trend. Root distribution of carbon stocks was in a fusiform, it increase with the increase of forest age. Results provide reference data for Sandy ecosystem carbon storage estimation.

\section{Introduction}

S. gordejevii is a perennial shrub, it is cold-resistant, heat-resistant, anti-sandstorm, easy propagation, growing fast, resistant to sand burial, light-preferring; it was likely to be born in the fixed dune grassland, semi-fixed dunes with high water table ${ }^{[1]}$; this species is one of the most ideal afforestation species for desertification control in Aohanqi Chifeng City, and it plays an important role governance and restore the ecological environment quicksand project in the area. S. gordejevii-related researches mainly focus on physiological parameters, morphological characteristics, habits and cultivation methods, root distribution and canopy structure, S. gordejevii sand barrier and shrubs soil moisture dynamics and other aspects ${ }^{[2-6]}$.

Root distribution refers to roots space gradient distribution, and its characteristics determine the size of the effect of surface between vegetation and soil environment ${ }^{[7]}$. The study of roots mainly involves root biomass, length or surface area change with soil depth, distance from the stems of plants, the location between the neighborhood ${ }^{[8]}$. Research on S. gordejevii roots concentrated on root distribution, biomass and physiological characteristics. While there was no report on the distribution of root carbon storage features of S. gordejevii. This paper set S. gordejevii at age of $15 \mathrm{a}, 25 \mathrm{a}$ and $35 \mathrm{a}$ in Aohanqi sandificational zone as object, and studied distribution of carbon reserves and S. gordejevii roots in different forest age, providing reference for accurate estimates sandy ecosystem carbon stocks. 


\section{Materials and methods}

\section{General situation of thee studied area}

This study sited for the Aohanqi Sanditificational Chifeng City. This area is located in north-central Aohanqi geographical coordinates of latitude $41^{\circ} 50^{\prime}-43^{\circ} 01^{\prime}$, longitude $119^{\circ} 32^{\prime}-120^{\circ} 25^{\prime}$, covering an area of about $2056.60 \mathrm{~km}^{2}$. Located in the temperate semi-arid continental monsoon climate zone, this area has been endowed with an average annual rainfall of $350 \mathrm{~mm}$, and the average annual evaporation of $2450 \mathrm{~mm}$, the average annual temperature of 7 centigrade. Artificial forest vegetation are mainly water conservation forest, soil and water conservation forest and sand-fixing forest, the main tree species are Populus simonii, Prunus sibirica, Hippophae rhamnoides, Caragana microphylla Lam., Salix gordejevii Chang et Skv. and Hedysarumfruticosum and the like. The main herb for the lespedeza are lespedeza davurica, artemisia ,Setaria viridis, Corispermum hyssopifolium, Agriophyllum squarrosum, etc. It has an altitude of between 400-500m. Sandificational area mainly are flow, semi-flow, fixed sand and cover sandy earth, and the soil quality is poor.

\section{Sampling and testing}

\section{Sample selection and plots laid}

From July to August 2014, Chifeng City Aohanqi sandificational area were set three different forest age of gordejevii plots (Table 1). Shrub sample area set: according to the study on distribution maps of forest resources and forest distribution in different afforestation period provided by Aohanqi Forestry bureau to determine the investigation plot. Using random method to lay plots, each plot area is set to $30 \mathrm{~m} \times 30 \mathrm{~m}$, while setting three $10 \mathrm{~m} \times 10 \mathrm{~m}$ shrub plots within plots. In the actual sampling, according to the actual situation of forest land, the number and size of some samples has been appropriate adjusted, as detailed in Table 1.

Table.1 The basic situation of the study area plots

\begin{tabular}{|c|c|c|c|c|c|c|c|c|c|c|c|}
\hline \multirow{2}{*}{ Forest type } & \multirow{2}{*}{$\begin{array}{c}\text { Forest age } \\
\text { ( a ) }\end{array}$} & \multirow{2}{*}{ Coordinates } & \multirow{2}{*}{$\begin{array}{l}\text { Altitude } \\
\text { (m) }\end{array}$} & \multirow{2}{*}{ Aspect } & \multirow{2}{*}{ Slope } & \multirow{2}{*}{$\begin{array}{c}\text { Slope } \\
\text { position }\end{array}$} & \multicolumn{2}{|c|}{$\begin{array}{c}\text { Density } \\
\left(\text { strains } / \mathrm{m}^{2}\right)\end{array}$} & \multirow{2}{*}{$\begin{array}{l}\text { Height } \\
(\mathrm{m})\end{array}$} & \multicolumn{2}{|c|}{ Crown $(\mathrm{m})$} \\
\hline & & & & & & & $\begin{array}{c}\text { Plant } \\
\text { density }\end{array}$ & $\begin{array}{c}\text { Real } \\
\text { density }\end{array}$ & & EW & $\mathrm{SN}$ \\
\hline \multirow{3}{*}{$\begin{array}{c}\text { S. } \\
\text { gordejevii }\end{array}$} & 15 & $\begin{array}{l}\text { E120 } 00^{\circ} 56^{\prime \prime} \\
\text { N42 } 56^{\prime} 03^{\prime \prime}\end{array}$ & 402 & $\begin{array}{l}\text { Shady } \\
\text { slope }\end{array}$ & $12^{\circ}$ & $\begin{array}{l}\text { Lower } \\
\text { portion }\end{array}$ & 0.4 & 0.15 & 1.70 & 1.90 & 1.95 \\
\hline & 25 & $\begin{array}{l}\mathrm{E} 120^{\circ} 09^{\prime} 18^{\prime \prime} \\
\mathrm{N} 42^{\circ} 55^{\prime} 51^{\prime \prime}\end{array}$ & 400 & $\begin{array}{l}\text { Shady } \\
\text { slope }\end{array}$ & $17^{\circ}$ & $\begin{array}{l}\text { Lower } \\
\text { portion }\end{array}$ & 0.4 & 0.09 & 2.60 & 2.25 & 2.70 \\
\hline & 35 & $\begin{array}{l}\text { E120 } 00^{\circ} 02^{\prime \prime} \\
\text { N42 } 56^{\prime} 25^{\prime \prime}\end{array}$ & 397 & $\begin{array}{l}\text { Shady } \\
\text { slope }\end{array}$ & $15^{\circ}$ & $\begin{array}{l}\text { Lower } \\
\text { portion }\end{array}$ & 0.4 & 0.08 & 2.25 & 2.10 & 2.50 \\
\hline
\end{tabular}

\section{Collect and measure samples}

Model tree selection and forest age determination

In each S. gordejevii forest sample, selected three model tree from each quadrat the trees that grown well and whose forest average measurement factors are similar model. The forest age was provided by Aohanqi Forestry Bureau.

Methods to determine $\mathrm{S}$. gordejevii roots

Layered segmentation mining method has been applied. Taking model tree as center point, along the line of trees extends to two adjacent lines at a spacing of $1 / 2$ in the horizontal direction, a segment would be the period of each $25 \mathrm{~cm} \times 25 \mathrm{~cm}$; in vertical direction, each $10 \mathrm{~cm}$ was a layer, the layers of soil sampling volume was $25 \mathrm{~cm} \times 25 \mathrm{~cm} \times 10 \mathrm{~cm}$, then conducting layering excavation into the under 
border of the root system. The maximum vertical depth distribution of $\mathrm{S}$. gordejevii standard strain root was between $150-250 \mathrm{~cm}$. For each layer segment soil, crushed and sieved, carefully picked live roots, after cleaning the root surface, measuring the classification one by one with a caliper measurement. For root at all levels, taking appropriate samples back indoor for drying, then the measured moisture conversion factor which can be used for calculating dry weight of each interval root.

Test and determination of sample carbonaceous

Organic carbon content of S. gordejevii root can be tested by using potassium dichromate-sulfuric acid oxidation method.

2.3 Statistical analysis

Root carbon reserves: Root carbon reserves $=$ root biomass carbon reserves $\times$ carbon ratio.

Plan of determination area and profile were drawn by using Auto CAD Software; using Excel for statistical analysis of measurement data ; using Sufer software to draw distribution maps of root carbon reserves.

\section{Results and analysis}

\section{Vertical distribution of underground root biomass}

As can be seen from Figure 1, with the increase of soil depth, S. gordejevii root biomass presents the first increase then decrease trend, mainly in $0-100 \mathrm{~cm}$ soil, all account for more than $80 \%$ of the total. 15a S. gordejevii root biomass distributed in all the depth of the soil $0-190 \mathrm{~cm}$ and peaked at $30-40 \mathrm{~cm}$ soil. $25 \mathrm{a} \mathrm{S}$. gordejevii gained deepest roots of $240 \mathrm{~cm}$, root biomass peaked at $40-60 \mathrm{~cm}$ soil. $35 \mathrm{a}$ S. gordejevii deepest roots reached $250 \mathrm{~cm}$, root biomass peaked at $40-50 \mathrm{~cm}$ soil. total root biomass of $15 \mathrm{a}$ S. gordejevii Liu was $516.50 \mathrm{~g} ; 25 \mathrm{a}, 4448.60 \mathrm{~g}, 8.61$ times of $15 \mathrm{a} ; 35 \mathrm{a}, 7257.77 \mathrm{~g}$, 14.05 times of $15 \mathrm{a}$, indicating that as the forest age increase, $\mathrm{S}$. gordejevii root biomass grows.

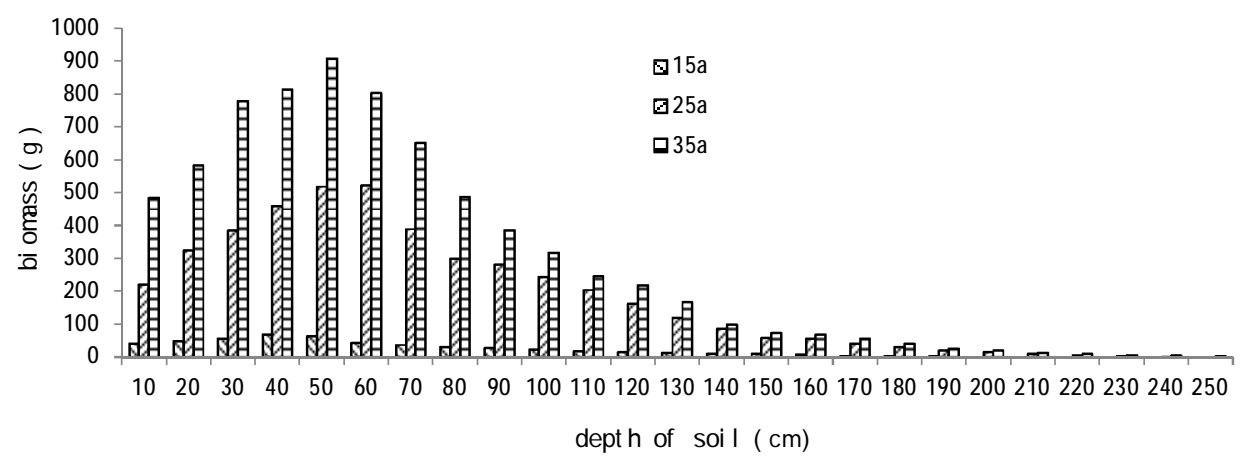

Fig.1 Vertical distribution of root biomass figure of S. gordejevii at different forest sge

\section{Root carbon reserves distribution figures}

From Figure 2, Figure 3 and Figure 4, people can see that S. gordejevii root distribution characteristics of carbon reserves presented a form of fusiform. In the vertical direction, with the increase depth in soil, carbon storage first increase and then decrease, 15 a peaked at $30-40 \mathrm{~cm}$ soil, a maximum of $0.93 \mathrm{~g} / \mathrm{m}^{2}$, peak of $25 \mathrm{a}$ and $35 \mathrm{a}$ appears in $40-50 \mathrm{~cm}$ soil; in the horizontal direction, the farther away from the center of the model tree, the less the root carbon storage is, mainly in a range of $75 \mathrm{~cm}$ from model tree center.

15a S. gordejevii root carbon reserves of $30.81 \mathrm{~g} / \mathrm{m}^{2}$, in horizontal direction, carbon storage range of each segmentation is $0.77-7.00 \mathrm{~g} / \mathrm{m}^{2}$, the vertical range of $0.15-4.11 \mathrm{~g} / \mathrm{m}^{2} ; 25$ a root carbon 
reserves of $158.56 \mathrm{~g} / \mathrm{m}^{2}$, range of $3.96-36.16 \mathrm{~g} / \mathrm{m}^{2}$ in the horizontal direction, and $0.04-18.52 \mathrm{~g} / \mathrm{m}^{2}$ in the vertical; $35 \mathrm{a}$ raw root carbon reserves is $229.99 \mathrm{~g} / \mathrm{m}^{2}$, the level of carbon stocks in each direction range is $5.74-52.44 \mathrm{~g} / \mathrm{m}^{2}$, each vertical carbon storage range is $0.07-28.87 \mathrm{~g} / \mathrm{m}^{2} .25 \mathrm{a}$ root carbon reserves is 5.14 times of $15 \mathrm{a}, 35 \mathrm{a}$ is 7.46 times of $15 \mathrm{a}$, indicating gordejevii root tended to increase with the increase forest carbon reserves age.

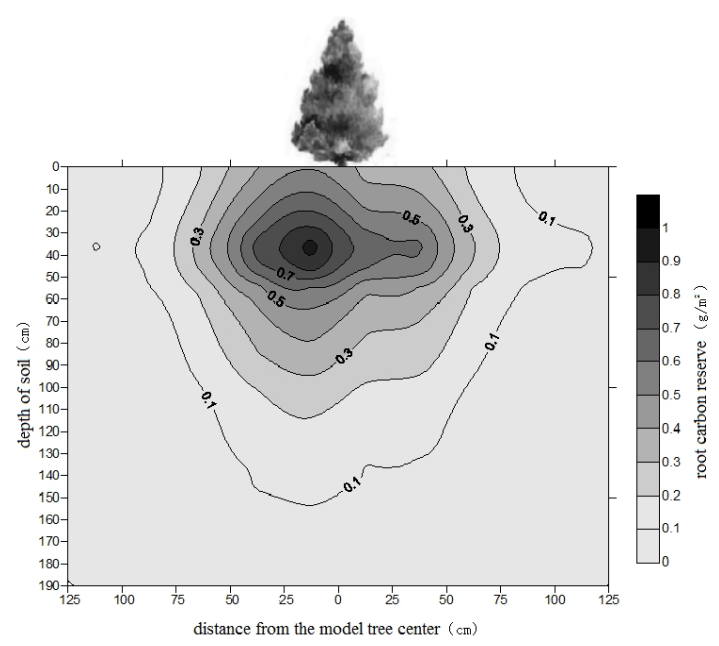

Fig.2 Vertical distribution of carbon stocks figure of $15 \mathrm{a}$ S. gordejevii root

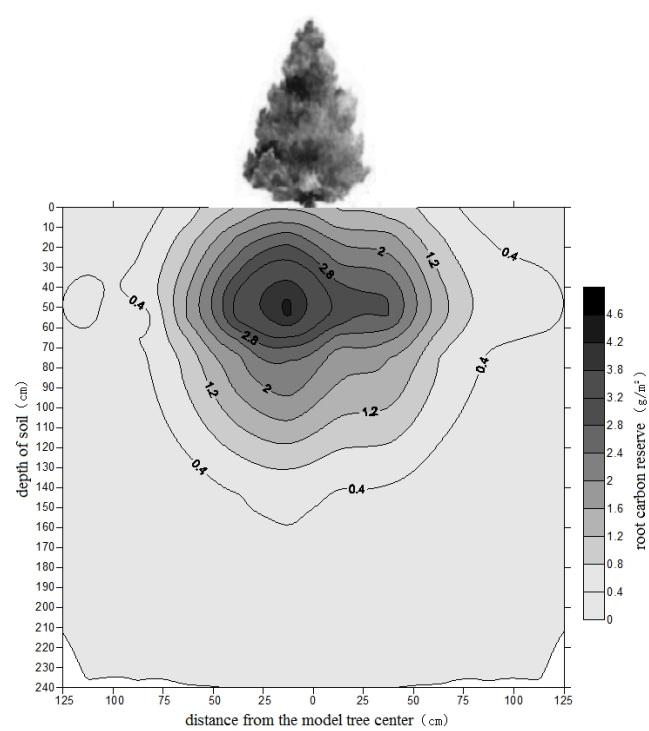

Fig.3 Vertical distribution of carbon stocks figure of $25 \mathrm{a} \mathrm{S}$. gordejevii root

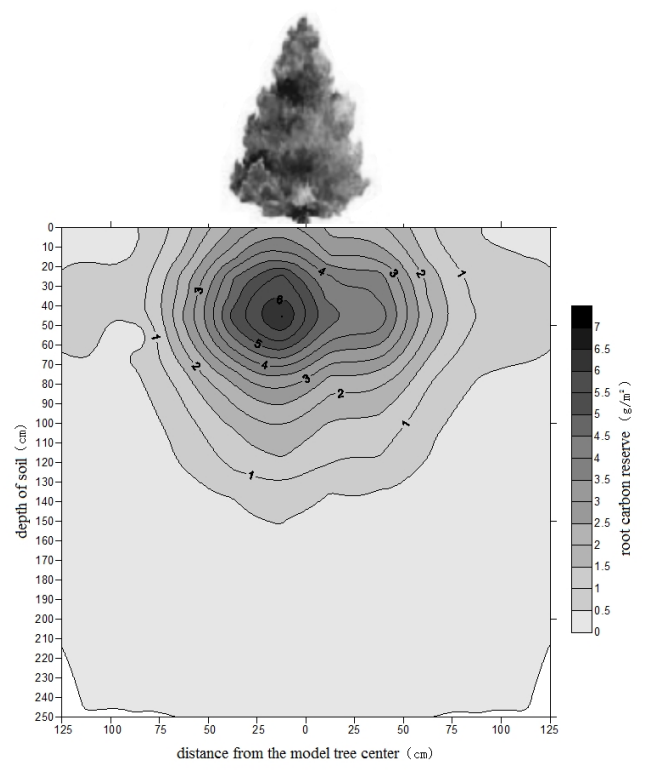

Fig.4 Vertical distribution of carbon stocks figure of $35 \mathrm{a} \mathrm{S}$. gordejevii root

\section{Conclusion}

With the increase of soil depth, S. gordejevii root biomass shows a trend of first increasing the decreasing, mainly in soil of $0-100 \mathrm{~cm}$, accounted for more than $80 \%$ of the total roots; with an increase in forest age, S. gordejevii root biomass shows growing trend. Distribution of root carbon reserves presents in a form of fusiform, and is in an increasing trend with the increase of forest age; in the vertical direction, with the increase in soil carbon storage root depth shows a trend of first reduce and then increase; in the horizontal direction, the farther away from the center of the model tree, the less root carbon storage is, mainly in a range of $75 \mathrm{~cm}$ from model tree center. 


\section{Acknowledgements}

This work was financially supported by the Inner Mongolia applied research and development program (Key Technologies of Carbon Sequestration in Agriculture, Forestry, Animal Husbandry Coupled Ecosystem), (20110732). The project supported by National Natural Science Foundation of China that (Influence mechanism that Caragana stumps have on plant roots and soil moisture in Inner Mongolia pastoral transitional zone),( 31500584).

\section{References}

[1] Chunping Miao, Xuehua Li, Deming Jiang. Arid zone research, Vol. 29.(2012), pp. 208-212.( In chinese )

[2] Haiyan Zhou, Aifen Zhao. Chinese bulletin of botany, Vol. 17.(2000), pp. 543-547. ( In chinese )

[3] Xueli Chang, Shenggong Li, Xueyong Zhao. Research of the growth of Salix gordejevii thickets and above-ground ecology. Gansu Science Press, Lanzhou, 1993. ( In chinese )

[4] Anzi Ren, Yubao Gao, Jinlong Wang. Acta Ecologica Sinica, 21(2001), pp. 399-404.( In chinese )

[5] Zhenqi Lu, Shuang Li, Chenguang Li, et al. Journal of agricultural university of hebei, 36(2013), pp. 26-32. ( In chinese )

[6] Xiangfei Yue, Jianhuan Cui, Tonghui Zhang, et al. Journal of Arid Land Resources and Environment, 27(2013), pp. 74-80. ( In chinese )

[7] Fitter A. Characteristics and function of root systems, Plant roots:the hidden half(Second edition), marcel Dekker,Inc., New York, 1996, pp. 1-20.

[8] Lynch J, Nielsen K L. Simulation of root system architecture, Plant roots:the hidden half(Second edition), Marcel Dekker, Inc., New York, 1996, pp. 247-250. 